\title{
The Discursive Representation of Women in the Algerian Family Code "The Case of Marriage and its Dissolution" CDA Approach
}

\author{
Zohra Bekhedda \\ University of Mostaganem
}

\begin{abstract}
The present research analyses the discursive representation of women in the Algerian family code of 2005. It draws on critical discourse analysis (henceforth CDA) framework in an effort to shed light on the way women are discursively represented in the amended Algerian family code. For this particular purpose, the aforementioned legal text is linguistically examined following a CDA framework with a special emphasis on Van Leewen's $(1996,2008)$ sociosemantic model of analysis. The latter is employed to explore how women as 'social actors' are represented aiming to uncover the way power, dominance, bias, and ideologies are maintained in the target discourse. The analyses of this study reveal that the Algerian family code maintains and perpetuates women's inferior position. These findings indicate that gender bias and asymmetrical power relations are enacted in the Algerian Family code in relation to marriage and its dissolution.
\end{abstract}

Keywords: Algerian Family Code, marriage and its dissolution, discursive representation, Critical Discourse analysis, social actors, gender bias. 


\section{1-23 December, 2018 in Berlin - Germany}

\section{Introduction}

The Algerian family code is a set of legal provisions governing the family relationships. Therefore, this code provides some guidelines for marriage and its dissolution to protect the rights of the family and society as a whole. Ensuring women's rights in the domain of family and marriage has been regarded as the prominent focus of the amended Algerian Family Code.

This research analyses the representation and the status of women in the amended Algerian family code. Indeed, the representation of women in this kind of discourse depicts their social position and it is significant to maintain their dignity and status which can minimize the gap in gender inequality. In fact, if the law becomes controlled and dominated by men, it may harm women in the sense that it will hinder their legal advance as effective members in a society.

In the last decade, there have been noticeable reforms in the Algerian Family Code. These amendments affect the struggle to improve the rights of women in the institution of marriage and its dissolution. In addition, they developed around a general principle of extending the protection of woman within the family, and so women seem to gain more rights in regard to marriage, divorce, polygamy, custody, and alimony.

Then, in this paper, Critical Discourse Analysis (henceforth CDA) is provided as an approach to examine the way women are represented in the Algerian family code. Hence, CDA is employed to analyze the Algerian family code of 2005 and explore how power, dominance, bias, and ideologies are maintained in the target context.

In brief, this study critically and discursively analyses the amended Algerian family code about marriage and its dissolution and investigates the portrayal of women in it.

\section{Statement of the Issue}

The present study applies a CDA approach to the target code in an effort to shed light on women discursive representation the abovementioned type of discourse. Therefore, the theoretical framework on which this research is based on is CDA following Van Leeuwen's (2008) model of analysis.

Interestingly, scholars in the field of CDA generally argue that social practice and linguistic practice complete one another and concentrate on how societal power relations are maintained, exercised and reinforced through the use of language.

Additionally, this research employs Van Leeuwen's model of analysis to investigate the representation of women in the target discourse by considering the representation of social actors. This model is chosen since it enables the researcher to study some of the main discourse strategies found in the selected articles and infer the embedded ideological structures.

\section{Research Questions}




\section{1-23 December, 2018 in Berlin - Germany}

The current paper intends to answer the following research questions:

1)-How women are discursively represented in the amended Algerian Family Code in relation to marriage and its dissolution?

2)-How women are talked about in the Algerian Family Code and whose interest is served by this representation.

\section{Research Aims and Objectives}

This study aims to increase knowledge of the current condition of the family and the representation of woman in the new Algerian Family Code. Therefore, the purpose of this research is to develop a better informed even detailed understanding of the amended code about marriage and its dissolution by considering both the representation and the constructed position of woman in this discourse. Consequently, the Algerian family code will be analyzed to uncover the target discourse and dissect it critically to investigate how meaning is constructed.

Furthermore, the major objective of this study is to increase knowledge about the representation and position of women in the family code as well as to account for the representation of women and detect important aspects of how they are discursively portrayed in the new Algerian Family Code vis-à-vis marriage and its dissolution. Additionally, it seeks to sensitize the people to gender issues about women's status in the target discourse and to raise the women's consciousness of their civil rights in the new Family Code.

\section{Significance}

This research analyses the main ways in which women are represented as social actors and their portrayal in the Algerian Family Code. Importantly, it is significant to explore a new area of research that received little attention from researchers in the field of sociolinguistics and gender studies. Moreover, the results of this study could turn the attention of the decision makers to legitimize the voices of women and improve their portrayal in the legal discourse in general and in the family code in particular. Thus, this study is an endeavor to increase the sensitizing of the Algerians as a whole (both women /men) to gender issues about women's status in the target discourse. More precisely, the results of this study can play a major role in raising women's consciousness of their representation and status in the New Algerian Family Code. In short, this study can provide a clear understanding of how meaning is constructed in this particular type of discourse.

\section{Conceptual Framework}

\section{Critical Discourse Analysis}

While critical discourse analysis did not emerge as a separate discipline until the late 1960s, its earliest history can be traced back to critical linguistics (often abbreviated as $\mathrm{CL}$ ), a research 


\title{
21-23 December, 2018 in Berlin - Germany
}

paradigm which is developed by a group of scholars from the University of East Anglia namely Roger Fowler, Robert Hodge and Gunther Kress at in the 1970s (Fairclough 1992, 25; Thornborrow 2002, 14).

Therefore, the modern center of attention of CDA on language and discourse originated from Critical Linguistics which appeared in the UK and Australia at the end of the 1970s (Fowler et al, 1979). Though CDA is based on Critical Linguistics (henceforth CL) (Rogers, 2004), it steps $\mathrm{CL}$ in such a way that $\mathrm{CL}$ stepped Chomskyian formal grammar and description.

This approach was based on Halliday's Systemic Functional Linguistics (SFL).Essentially, CL practitioners intended at "isolating ideology in discourse" and analyzing "how ideology and ideological processes are operating as two systems of linguistic criteria and processes. Drawing on Halliday's view, $\mathrm{CL}$ emphasizing language in use which perform three patterns: ideational, interpersonal, and textual patterns. It advocates the central thought that enables the researchers to go beyond the descriptive analytical study of the linguistic forms moving to the critical study of the social acts (Halliday, 1973, 1978).

Halliday's view of language as a "social act" is a fundamental idea that is widely used by CDA theorists (Fairclough, 1989; Chouliaraki and Fairclough, 1999; Fowler et al., 1979). According to Fowler et al. (1979, p. 185), draws a comparison between CL and sociolinguistics asserting that:

\begin{abstract}
"There are strong and pervasive connections between linguistic structure and social structure" on the other hand, whereas in sociolinguistics "the concepts 'language' and 'society' are divided...so that one is forced to talk of 'links between the two'", for CL "language is an integral part of social process" (Fowler et al., 1979, p. 189).
\end{abstract}

Hence, for Fowler, the two concepts language and society are distinctly approached by sociolinguists and critical linguists. Unlike $\mathrm{CL}$, sociolinguistics views the target concepts as two different parts of the social process.

Another essential hypothesis of CDA and SFL is that selections are made by speakers with regard to vocabulary and grammar and that these selections are deliberately or unintentionally "principled and systematic"(Fowler et al., 1979, p. 188). Therefore the linguistic choices are not done at random but they are based on ideological assumptions.

Thus, CL emphasizes a strong relationship between language, thought, and culture. It deals with the study of a language in its social and historical context. Critical linguists believe that any linguistic form can bear the ideological connotation. (Fowler 1991, 67 )

Fairclough's (1989), asserts that there is a complementary relationship between CL and CDA, as in both of them language is viewed to be socially and ideologically determined (Sheyholislami , 2001). In brief, language is viewed as a social practice which is ideologically based. 


\section{1-23 December, 2018 in Berlin - Germany}

Another line of influence and development goes back to Classical Rhetoric, and some other sub-branches of linguistics such as Sociolinguistics, Applied Linguistics and Pragmatics (Weiss and Wodak, 2002).

Wodak (2011,p50) argued: "The roots of CDA lie in classical Rhetoric, text linguistics and Sociolinguistics, as well as in Applied Linguistics and Pragmatics" (see also Wodak \& Meyer 2009; Fairclough 2003; Wodak 2004, 2007; Renkema 2004;Blommaert 2005) .

Moreover, CDA was developed by the Marxist and post-modernist approaches of social theorists, such as Foucault (1972) and social linguists, like Pecheux (1975), who made a link between ideology and discourse. In the 1930s the Russian scholars Bakhtin and Vološinov claimed an integration of language together with the social practices. This claim has influenced many theorists in the field like the French scholar Pecheux (1982), who based his approach at this theoretical background (Wodak2011). This view is considered as the crucial mechanism to understand and reveal the embedded ideologies.

Later on from the 1960s, many theorists turned their attention to a more critical perspective of the study of language. by the late 1970s, a new term, critical linguistics(often abbreviated $\mathrm{CL}$ ), was coined by a group of linguists from the University of East Anglia. This group employed this term in their studies about the use of language in multiple institutions.

Furthermore, CDA was also deeply influenced by the philosophy of some social theorists like Jürgen Habermas and the critical theory of the Frankfurt School (Van Dijk, 1993).

In1979 Fowler; Kress \& Hodge suggested strong and omnipresent associations between linguistic forms and social functions, arguing that there is no existence to discourse without social meanings (Fairclough 1992, 25; Thornborrow 2002,14)Since that period (1979), this broad approach has been revised altered and re-applied by a number of scholars from various linguistic schools. Most of these linguists believe that the complex relationship between language and society necessitates an interdisciplinary approach which goes beyond the linguistic frame extending to include other branches/and or sub branches of study such as literature, psycholinguistics, sociolinguistics, and other domains such as ethnicity, race,gender ...Etc

The main concepts of discourse, which are used nowadays in CDA were coined, used and developed by social scholars like (Foucault 1972; Bourdieu 1974),linguists(e.g., Saussure 1959; Schiffrin et al, 2001) (ChavalinSvetanant, 2009).

Van Leeuwen (2006) suggested that most of CDA's concepts are derived from Fairclough's works from (1989), who used some terms such as critical discourse analysis, Critical Language Awareness (CLA) and Critical Language Studies (CLS). Besides, In (1992), he used Critical Language Awareness (CLA) and used critical discourse analysis as a whole phrase without abbreviation positioning critical discourse analysis as a form of CLS. Later on in (1995), an influential conceptual change was witnessed with the publication of Fairclough's new book "Critical Discourse Analysis". Similarly, Van Dijk (1993) argues there are no obvious borders 


\section{1-23 December, 2018 in Berlin - Germany}

between $\mathrm{CDA}$ and $\mathrm{CL}$ and both "are at most a shared perspective on doing linguistic, semiotic or discourse analysis" (p. 131).

Like the adjacent disciplines, CDA's emergence can be considered as a response against the prevailing assumptions (often "asocial" or "uncritical ") of the 1960s and 1970s.

Similarly, it flourished in France, moving to in the UK and the USA, the works of Althusser (1971), Foucault (1972), and other scholars can be also considered as prominent to CDA. Antonio Gramsci (1891- 1937), together with his group in France and the UK, namely Stuart Hall and the other scholars of the Centre for Contemporary Cultural Studies (Hall, 1981) also played a crucial role in the development of CDA

Moreover, the feminist researches have an inevitable influence on the significant study of language and communication (Van Dijk, 1995).In the 1980s, a new line to the study of CDA has noticed beginning with discourse analysis when a group of linguists, such as Fairclough, Van Dijk, and Wodak started to approach language within its context. In the beginning, they tend to analyze the relationship between discourse and society. It was recognized as a movement in 1992, at a Amsterdam in a meeting in which the members of the same group had, this meeting gave birth were later to the publication of "Discourse and Society" in 1993. The meetings of the scholars were held once a year from 1992 onward, the period in which numerous significant papers and two academic journals came into sight from 2004: namely, Critical Discourse Studies and the Journal of Language and Politics (Van Leeuwen, 2006).

As it is previously mentioned CDA has emerged thanks to the development of some adjacent disciplines such as linguistics, anthropology, philosophy, socio-psychology, Cognitive Science, Literary studies and Sociolinguistics, as well as Applied Linguistics and Pragmatics Wodak and Chilton (2007).

Cda is considered as both a theoretical and methodological framework used in analyzing discourse. "CDA needs to be understood as both a theory and a method" (Chouliaraki and Fairclough 1999,p16)

As far as the functions of CDA are concerned, Rogers (2004) declared that critical discourse analysis is used not only to describe and interpret discourse in a particular social environment ; but it also, presents a systematic clarification about the way discourse operates "Not only a description and interpretation of discourses in social context but also offers an explanation of why and how discourses work"(p.2)

In addition, it has several other functions such as revealing the concealed realities and detecting power relations and ideologies that are strengthened by members of society.

"Critical discourse analysis is a type of discourse analytical research that primarily studies the way social power, abuse, dominance, and inequality are enacted, reproduced and resisted by text and talk in the social and political context".(Van Dijk 1994,p.352) 


\section{1-23 December, 2018 in Berlin - Germany}

Similarly, Weiss and Wodak said: "CDA takes a particular interest in the relationship between language and power."(2002, p12)

Scollon(2001), CDA is the plan of investigating socially and critically discourse. It is considered as a means of creating a change in society "a program of social analysis that critically analyses discourse_that is to say language in use _as a means of addressing social change" (p.140)

It relates language within the social context which can be analyzed within one scope by building up a conversation between them. (Meyer,2001) stated: "It is generally agreed that CDA must not be understood as a single method but rather as an approach, which constitutes itself at different levels and each level a number of selections have to be made"(p.14)

In addition, CDA combines both the microanalysis of texts and the macroanalysis of social aspects of life.On this concern, Luke explains: "CDA involves a principled and transparent shunting backward and forth between the microanalysis of texts using varied tools of linguistics, semiotics, and literary analysis and the microanalysis of social formations, institutions and power relations that these texts index and construct"(Luke 2002,p.100)

Hence, CDA 's main focus is to uncover the way injustice and social power, control and unfairness are reproduced within a specific context. It emphasizes how power is implemented through discourse

\section{Van Leeuwen Socio-Semantic Network}

Van Leeuwen approach will be used to examine the representation of women in the target discourse considers the representation of social actors. This model enables the researcher to study some of the main discourse strategies found in the selected articles to refer to women in relation to marriage and its dissolution.

Leeuwen's (2008) theoretical framework will be used for a better understanding of social practices through discourse. Van Leeuwen $(1996,2008)$ suggests some general categories and some subtypes refer to social actors in discourse: exclusion or inclusion. Exclusion is divided into two strategies: backgrounding and suppression; whereas, inside inclusion, the following types are distinguished: Role allocation, Generalisation, specification (generic or specific reference, i.e., representation as classes or as individuals); assimilation (representation of people in groups), association (groups of social actors), dissociation (unformed associations); indetermination (unspecified representation of social actors), differentiation (specification of the different social actors); nomination (reference to the unique identity of social actors) ,categorisation (identities and functions shared with others), functionalization, identification (reference to social actors in terms of something they do or what they are), personalisation (representation of social actors as human beings or not) and finally, overdetermination (representation of social actors as participating in more than one social practice). In brief, Van 


\section{1-23 December, 2018 in Berlin - Germany}

Leeuwen's model of analysis is important to investigate the way social actors can be involved in a particular discourse or marginalized from it.

\section{Research Methodology}

\section{Samples}

My analysis draws upon fifteen articles taken attentively from the amended Algerian family code, which was issued in Algeria and run by the republic president Abdelaziz Bouteflika from 2005 till the present days. Interestingly, in the present study, the version of the Algerian Family Code I am using is that of 2005 which is originally written in Arabic (the most recently amended version). This version is originally written in Arabic, published by Dar Ennadjah Livre in 2006 in Algeria and reissued in 2007.

One reason for the selection of articles is the fact that they deemed controversial because they are suddenly being amended in an unprecedented manner creating a great debate about the 'new' code and its impact on women and society on the whole.

\section{Data Collection and Data Analysis Procedures}

Since the selected articles are originally written in Arabic, translation is an inevitable step before their analysis. So, all of the fifteen articles were carefully translated into English and analyzed using Van Leeuwen's model of the representation of social actors. After identifying the main strategies suggested by Van Leeuwen, the obtained data were presented in tables, explained and interpreted within the CDA framework.

\section{RESULTS AND DISCUSSION}

As it is previously mentioned, the methodological framework of this study is Van Leeuwen's socio-semantic model of social actors. Therefore, drawing on Van Leewen's model of analysis, the obtained data evince a pattern of inclusion of social actors both together with exclusion in certain articles.

The results of this study can be summarized as follows:

\section{Exclusion or Inclusion}

Exclusion: It is divided into back grounding and suppression: Women in the Amended Algerian family code are represented as passive recipient of the social action by being totally suppressed or back grounded. 
Art.9 bis. (New) -...The capacity to marry. (Nominalization)... ...El Wali, .... (Backgrounding) ...

...Exemption from legal impediments to marriage....(Nominalization)

Art. 8 bis 1. (New)-.

..The new marriage would be terminated before its consumption (dukhul) ...(Suppression)

These above articles have shown that in the institution of marriage, women are excluded from the social actions denoting either the tendency of hiding the identity of the social actor (as it is the case in the use of nominalization), or the fact that the identity of the social actor is obvious(as it is the case for the Wali since it is recommended only for woman)

\section{Inclusion}

The following types of inclusion are employed in the target discourse:

Role allocation: As this strategy very clearly demonstrates the activation or the passivation of social actors, it is important to mention that wom en are mostly represented as dynamic social actors who are often associated to certain activities. However, this does not mean that they are not passivated. Throughout the data, it is noticed that women are not given the chance to be active in certain social activities and they are rather recipient and/or beneficialised from some legal rights. This will be illustrated by the following examples:

Art. 7. (Modified) The minor spouse acquires the capacity to sue for the rights and obligations arising from the marriage contract (Activation)

Art. 8 bis. (New) - In case of fraud (tadlis), each wife can file for divorce against the spouse. (Circumstantialization by the use of a propositional Word 'against')

Art. 11. (Modified) -The major woman helds her marriage contract...( Activated action)...

Art. 19. (Amended) -.... may stipulate in the marriage contract or in a formal additional contract...(Activation)

Art. 54. - (Modified) - The wife may separate from her spouse without his agreement (Activation)

Art. 7. (Modified) - Marriage capacity is deemed valid at the age of 19 years old for men and women (Beneficialization).

Art.9.(Amended)-The marriage contract is held by the exchange of the consent ...(Passivation). 
Art.11.(Modified) -...the marriage of the minor is contracted by through her "wali", (Passivation)

Art. 74. -...the husband is required to provide for the maintenance of his wife (Beneficialization).

Art. 31. (Amended) - The marriage of Algerian(man) and Algerian (women) with foreigners of both sexes is governed by regulations (Passivation)

Differentiation/Individualization: Differentiation is often associated with individualism, indicating that a particular social actor is special and different from the other social actors participating in the social practice.

Art. 10. - Consent follows from the request of one of the two parties (Individualization) and the acceptance of the other( Differentiation )

Art. 8 bis. (New) - In case of fraud (tadlis), each wife can file for divorce .(Individualization )

Identification : The strategy of identification is overused in the Amended Algerian family code especially relational identification which emphhasis the kinship relationships between the social actors. Moreover, identification is subdivided into classification, relational identification and physical identification.

It is expressed in the investigated articles by employing three terms which were repeatedly employed in the Algerian Family code, these terms are :the wife, the spouse and the mother. As it is noticed ,the use of these terms law represented places women as a subordinate to their male kins (patriarch) who are given more strength to control and 'protect' them. Hence ,the code encourage and perpetuates patriarchal domination. This statement is supported by the following examples:

Art. 11. (Modified) -....the marriage of the minor is contracted by through her "wali", who is the father, then one of the close relatives(relational identification).

Art. 7. (Modified) - Marriage capacity is deemed valid at the age of 19 years old for men and women (classification).

Art. 64.(Modified) -The right of custody devolves first to the mother (relational identification) of the child.

Genericization: It can be realized by the representation of social actors as groups employing plural without articles or singular with the use of definite or indefinite articles.

By way of illustration, the following articles clarifies the use of genericization in the analysed code:

Art 62.- ........ The holder of this right(al haadin)must be able to take charge of it. (The use of singular with definite article).

Art. 19. (Amended) - Both spouses may stipulate in the marriage contract . 


\section{1-23 December, 2018 in Berlin - Germany}

Art. 7. (Modified).... when the aptitude for marriage of both parties is established.

Art. 31. (Amended) - The marriage of Algerian(man)_and Algerian (women) with foreigners.

Descriptivation /Specification/ Spatialization:These three strategies are also found in the targeted discourse, however their use is limited only to the undermentioned articles.

Art. 11. (Modified) -The major woman helds her marriage contract (Descriptivation )

Art.8.(Modified)-It is permissible to get married to more than one wife(Specification by the use of a numerative)

Art. 31. (Amended) - The marriage of Algerian(man) and Algerian women. (Spatialization)

As pointed out in the results some exclusions seem to be 'ideology-free' since the identity of the social actors is recognized; but others are not. They often entail embedded ideologies and, thus, tend to abolish the existence of social actors. The social actors are generally included by means of suppression or backgrounding. However, they are most of the times included via role allocation, relational identification, genericization, descriptivation, specification, spatialization.

From the previous examples, it can be seen that women are represented in a variety of ways in the investigated code. That's to say, they are excluded in certain articles and represented as inferior, subordinate or powerless social actors. Whereas, they are included in other cases and portrayed as active members who play important roles in the social action. Interestingly, this case of the study confirms the importance of improving the representation of women in the Algerian family code in relation to marriage and its dissolution.

\section{Conclusion}

This paper was an endeavor to highlight the discursive representation of women in legal discourse. Articles from the amended Algerian family Code in relation to marriage and its dissolution were chosen to fulfill the objectives of this study. By opting for Critical Discourse analysis approach to analyze the research data, this study attempted to reveal the way meaning is reproduced in the discourse under scrutiny.

The findings of this study indicated that women are discursively represented in a variety of ways. Via inclusion strategies, women were depicted as active, dynamic, expressive and assertive.On the other hand, they were passivated or completely excluded indicating their inferior position and their subordination to the male kin. In fact, women have always been looking for enhancing their rights in society, however, their discursive representation is still governed by some patriarchal beliefs.Since women live in a social context, they are often represented in terms of 'Who they are', 'Whose daughters or spouses are they, and 'how are they thought about in a society, this can deeply generate a representation which is fully context dependent.For instance, when it comes to the capacity of marriage the major woman 


\section{International Conference on}

\section{SOCIAL SCIENCE, HUMANITIES \& EDUCATION}

\section{1-23 December, 2018 in Berlin - Germany}

is given the right to choose her partner, however, the presence of her wali(the male patriarch ) is needed although it is not obligatory except in some situations. That is to say, women do and receive actions and their representation is context dependent and ideologically guided.

All in all, it seems that the Algerian legislator has attempted to enhance women's rights by giving them more privileges in relation to polygamy, khulaa (divorce by compensation), custody and alimony. However, women are still marginalized and dependent to their male kin and all the efforts of empowering them from patriarchal domination seem to be insufficient. Thus, the efforts of the legislator are worth and really appreciated but they are still insufficient to free women from the patriarchal domination Women are still waiting a chance for their voices to be heard and their rights to be more enhanced and legal innovation is therefore required.

This research suggests further research through which women's representation can critically be investigated. The whole family code can have the better chance of being uncovered. Van Leeuwen's framework $(1996,2008)$ can also be used to investigate the way men and other members in the Algerian family are discursively represented in the Algerian family code of 2005. 


\section{1-23 December, 2018 in Berlin - Germany}

\section{REFERENCES}

Blommaert, J. (2005), Discourse. Cambridge: Cambridge University Press.

Bourdieu, P. ( 1974).Cultural Reproduction and Social Reproduction. In: Karabel, J., \&

Chouliaraki, L., \& Fairclough, N. (1999). Discourse in Late Modernity: Rethinking Critical Discourse Analysis. Edinburgh: Edinburgh University Press. Halsey, A. H. (eds.) Power and Ideology in Education. Oxford University Press, New York.

Fairclough, N. (1989). Language and power. (2nd revised ed. 2001).London: Longman.

Fairclough, Norman. (1992). Discourse and Social Change. Cambridge: Polity Press.

Fairclough, N. (1995). Critical Discourse Analysis: The Critical Study of Language.

Harlow: Longman.

Fairclough, N. (2003). Analysing discourse: Textual analysis for social research. London: Routledge

Foucault, M.(1978 [1972]) The History of Sexuality: An Introduction. Vol 1. Harmondsworth: Penguin.

Fowler, Roger et al. (1979). Language and Control. London: Routlege \& Kegan Paul.

Fowler, R. (1991). Language in the news. Discourse and ideology in the British press. London: Routledge

Hall, S. (1981). The Determinations of news Photographs. In S. Cohen \& J. Young (Eds.), the manufacture of news: social problems, deviance and the mass media (Rev. ed., Vol. Communication and society. London: Constable.

Halliday, M. A. K. (1978). Language as social semiotic: The social

interpretation of language and meaning. London.

Halliday, M.A.K. (1973) Explorations in the Functions of Language. London: Edward Arnold.

Luke, A. (2002) Beyond Science and Ideology Critique: Developments in critical discourse analysis. Annual Review of Applied Linguistics.

Meyer, M. (2001). Between theory, method, and politics: Positioning of the approaches to CDA. In R. Wodak \& M. Meyer (eds.),Methods in critical discouse analysis, 1431. London: Sage.

Pêcheux, Michel (1975). Language, ideology and sematics. London: MacMillan

Pêcheux, M. (1982). Language, semantics and ideology. London: Macmillan.

Renkema, J. (2004). Introduction to discourse studies. Amsterdam: John Benjamins Pub.

Rogers, R. (Ed.). (2004). An introduction to critical discourse analysis in education. Mahwah, NJ, US: Lawrence Erlbaum Associates Publishers. 


\section{1-23 December, 2018 in Berlin - Germany}

Scollon, S. (2001). "Habitus, consciousness, agency and the problem of intention: How we carry and are carried by political discourses," Folia Linguistica.

Sheyholislami, J. (2001, September). Yesterday's "separatists" are today's "resistance fighters": A Critical Discourse Analysis. Ottawa: Carelton University.

Thornborrow, J. (2002). Power Talk. Language and Interaction in Institutional Discourse. London.

Van Dijk, T. A. (1993). Elite discourse and racism. Newbury Park, CA. Sage.

Van Dijk, T.A. (1994). Discourse structures and ideological structures. Papers presented at the international AILA Congress. Amesterdam.

Van Dijk, T. A. (1995). Discourse semantics and ideology. Discourse \& Society, 6(2), 243-289.

Van Leeuwen, T. (2006). Reading images: The grammar of visual design.London: Routledge.

Van Leeuwen, T. (2008). Discourse and practice: New tools for critical discourse analysis. New York: Oxford University Press.

Weiss, G./ Wodak, R. (2002): Visions of European Identities. Frankfurt Main: Velbrück (in press).

Wodak, R. (2004). Critical discourse analysis. In C. Seale, G. Gobo, J. F. Gubrium, \& D. Silverman (Eds.), Qualitative research practice (pp. 197-213). London: Sage.

Wodak R. and Chilton P. (eds.), (2005). A New Agenda in (Critical) Discourse Analysis: Theory, Methodology, and Interdisciplinarity.Amsterdam/ Philadelphia, John Benjamins.

Wodak, R., \& Meyer, M. (2009). Critical discourse analysis: History, agenda, theory, and methodology. In R. Wodak \& M. Meyer, Methods of critical discourse analysis. (2nd ed.)(pp.133). London: Sage.

Wodak, R. (2011). "Critical Linguistics and Critical Discourse Analysis." In Discursive Pragmatics: A Handbook of Pragmatics Highlights, edited by J. Zienkowski, J. Ostman, and J. Verschueren. 